\title{
Direct and Indirect Interactions between Landscape Structure and Invasive or Overabundant Species
}

\author{
Amanda D. Rodewald ${ }^{1} \cdot$ Peter Arcese $^{2}$
}

Published online: 27 May 2016

(C) Springer International Publishing AG 2016

\begin{abstract}
We reviewed recent literature to evaluate interactions between landscape structure (i.e., composition and configuration of landscapes) and overabundant and/or invasive species or "undesirable" species. Undesirable species are strongly associated with fragmented landscapes, especially those with linearly arranged elements to facilitate dispersal, and with land uses that serve as population sources. In some cases, structural legacies, such as land use histories, were as important as current landscape patterns. Many undesirable species also influenced landscape structure by altering disturbance regimes via a wide range of abiotic and biotic mechanisms, including by affecting abundance of keystone, foundation or engineering species at landscape scales, and by changing species interactions in ways that prompted community-level changes. In some instances, the effects of species on landscapes facilitated invasion and/or population growth to establish positive feedback cycles. Understanding the reciprocal effects of landscape pattern on invasive and overabundant species can help guide effective management strategies by increasing the cost-efficiency of conservation investments and prioritizing conservation actions.
\end{abstract}

Keywords Ecosystem · Exotic - Invasive · Fragmentation · Landscape $\cdot$ Species interactions $\cdot$ Indirect effects

This article is part of the Topical Collection on Effects of Landscape Structure on Undesired/Over-Abundant Species and Ecological Processes

Amanda D. Rodewald arodewald@cornell.edu

1 Cornell Lab of Ornithology and Department of Natural Resources, Cornell University, Ithaca, NY, USA

2 Department of Forest and Conservation Sciences, 2424 Main Mall, University of British Columbia, Vancouver V6T 1Z4, Canada

\section{Introduction}

The structure and function of landscapes are intimately related, and a major tenet of landscape ecology is that landscape structure (i.e., the types and arrangements of landscape elements; composition and configuration) and ecological processes or functions interact, often in a reciprocal manner $[1,2]$. These interactions can take a variety of forms, ranging from abiotic disturbances such as fire to biotic processes such as disease, outbreaks of undesirable pests or exotic species invasions, and can occur across a wide range of spatial scales where even local processes have the potential to scale up to influence landscape structure. There is growing interest and need in understanding the one-way and reciprocal interactions between individual species and landscapes, particularly for overabundant and/or invasive species deemed undesirable due to economic loss or threats to the persistence of native species and intact communities. There has been a long history of applying spatial models to the spread of species, including reaction-diffusion models, integro-difference equation models, neutral or percolation-based landscape models, and even newer approaches that consider species interactions (reviewed in [3]). However, our ability to apply such models in human-dominated landscapes still requires increased understanding about how species may interact as landscapes change, including the temporal nature of invasion processes and potential feed-backs.

In this article, we review recent literature to answer the following questions: (1) How does landscape composition and configuration, also referred to as landscape structure, affect overabundant and/or invasive species; (2) in what ways do these species, in turn, influence landscape structure; and (3) what is the evidence for reciprocal effects or feedbacks between the landscape and overabundant and/or invasive species? Throughout the article, we treat overabundant, 
expanding, and invasive species similarly, even if they differ in origin, and we recognize that invasive species may be native or non-native in origin. Collectively, these groups of species tend to be viewed as "undesirable" due to their direct or indirect economic impacts or direct or indirect impacts on the persistence of other native species or communities.

\section{Effects of Landscape Structure on Overabundant or Invasive Species}

The types and arrangement of spatial elements within landscapes mediate a wide range of ecological processes and species interactions [2], as evidenced by classic examples of landscape transformation leading to range expansions or population surges in native and nonnative species. The Brown-headed Cowbird (Molothrus ater), for instance, expanded from western to eastern North America after European settlers deforested and fragmented much of the East [4]. Likewise, the historic spread of bird-dispersed invasive plants across North America, such as Oriental bittersweet (Celastrus orbiculatus), was strongly linked to the changing geometry of heterogeneous landscapes [5]. More recently, regional changes in agricultural land use have prompted huge increases in the abundance of Snow Geese (Chen caerulescens caerulescens), leading to rapid habitat degradation and landscape transformation of arctic and subarctic systems [6].

Although these classic cases suggest that the influence that landscapes have on species is often predictable, other evidence indicates that more nuanced outcomes can develop, in part because the effects of landscape on species distribution or population growth can vary temporally and spatially. The temporal dimension is important because invasions occur in stages, as species are introduced, become established and then spread to maintain persistent populations [7,8]. At each stage, landscapes may influence the distribution, movements, or demography of species in ways that facilitate or repel invasion, depending on the resource needs and dispersal behavior of species, hostility of the landscape matrix and stage of invasion (Fig. 1, [9]). For example, landscape associations changed markedly over the course of the invasion of the Patagonian steppe by beaver (Castor canadensis) [10]. Small waterways in canyons initially facilitated their establishment, but as beaver populations grew, colonization was better predicted by the presence of plains, U-shaped valleys, and the proximity to existing beaver ponds [11]. Thus, the factors that facilitate species invasion may differ from those which predict establishment and potential distribution.

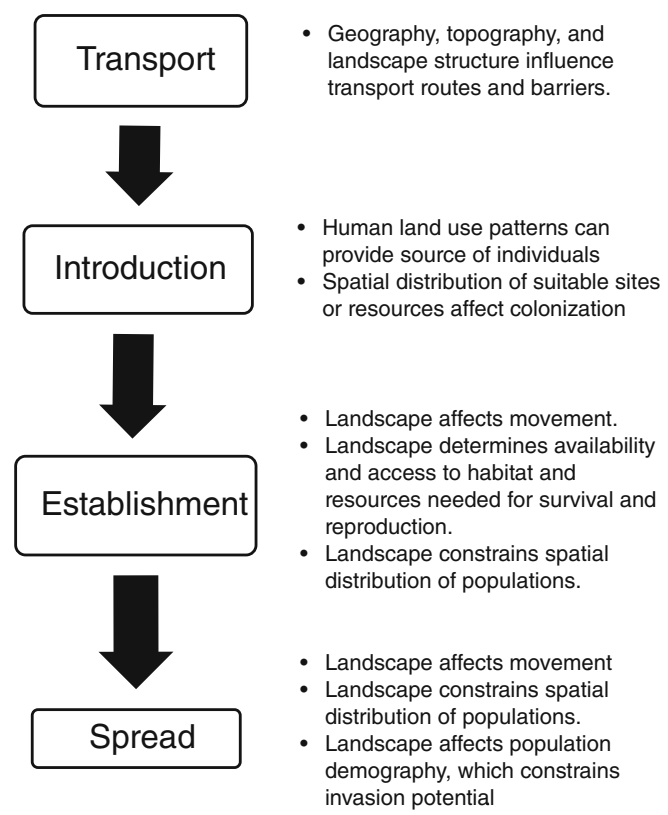

Fig. 1 The role of landscape structure can vary across the different stages of invasion. Adapted from With [8]

\section{How Does Landscape Structure Affect Overabundant and/or Invasive Species?}

There are four general ways that landscape structure can affect overabundant and/or invasive species. Landscapes can (1) serve as a source of individuals or propagules for introduction or immigrants to existing populations; (2) facilitate or retard movement or spread, directly by altering connectivity or distribution of satellite populations, and indirectly by affecting dispersal vectors; (3) influence demography by (a) affecting access to and availability of resources, (b) altering species interactions (e.g., releasing a species from predators or competitors, enhancing numbers of mutualists, affecting density of host or prey), or (c) shaping disturbance regimes; or (4) affect the vulnerability of native communities to resist invasion by way of mediating resources and disturbances that influence community structure. Below we provide examples of how common landscape attributes influence species via these mechanisms.

\section{Fragmentation}

Many studies show that overabundant and/or invasive species tend to spread most easily in fragmented landscapes [12]. Fragmentation can facilitate spread and overabundance by creating large amounts of early-successional and edge habitat within landscapes, thus providing resources for opportunistic species, corridors to facilitate their movement, disturbances that reduce the integrity of native communities, as well as potential vectors of spread due to association with high human activity. However, despite that generalization, we also must 
recognize that species responses will depend on their ecology. For example, feral cats and red foxes in Queensland, Australia were positively related to fragmented and heterogeneous agricultural landscapes [13], whereas fragmentation dampened spread of the introduced American mink (Neovison vison) in Scotland [14]. Thus, generalities about landscape structure must be considered within the context of the ecology of the species of interest.

Among the most distinguishing characteristics of fragmented landscapes are abundant habitat edges. Recent reviews confirm that non-native plants tend to be more abundant at fragment edges than interiors, in small isolated patches than large connected ones, and in human-dominated rather than natural landscapes [15-17]. These patterns suggest that small islands of natural habitat are unlikely to resist invasion without effective isolation from human-dominated landscapes or continued management of undesirable species. Such is the case where habitat edges and fragmentation promoted invasion of woodlands and forests by Noisy Miners (Manorina melanocephala) [18], an aggressive and spreading native species that excludes other birds and affects avian community structure at landscape scales [19]. There are exceptions to the pattern that small, isolated patches are most vulnerable to invasion. For example, in archipelago landscapes of the San Juan and Gulf Islands of the northwest coast of North America, native meadow communities on islands apparently benefitted from dispersal barriers related to isolation, as small and remote islands had the least invaded meadows [20] as well as relatively high occurrence of endangered species [21].

\section{Connectivity}

Connectivity of a landscape can be facilitated or retarded by fragmentation, spatial configuration of landscape elements, matrix characteristics, and disturbance regimes - to name a few examples - and collectively, these can profoundly affect movement rates within landscapes. Of course, the extent to which connectivity exists within a landscape depends upon the species in question. Connectivity in fragmented habitats is likely to increase for species adapted to disturbed habitats, but decrease for habitat specialists and species that avoid edges. Connectivity may also vary with landscape composition (e.g., habitat availability, specific land uses that are permeable to a given species) in addition to configuration, given that these two metrics often covary. Connectivity measured as habitat availability, independent of the existence of corridors, predicted spread in perennial pepperweed (Lepalium latifolium) in the San Joaquin River Delta [22], and, in simulation models, the potential spread of the exotic biofuel crop, Miscanthus $x$ giganteus [23].

Fragmented landscapes configured with lattice-like corridors or striped habitats also promoted faster spread than island-like landscapes [24, 25]. Linear anthropogenic habitats may be especially effective corridors that facilitate invasion at the landscape scale. Indeed, Maheu-Giroux and de Blois [26] showed that invasion of Quebec wetlands by Phragmites australis was promoted by anthropogenic, linear wetlands such as roadside or agricultural ditches, with facilitation strongest at intersecting transportation right-of-ways. Likewise, invasive Argentine black and white tegu (Tupinambis merianae) spread most in the Florida Everglades when disturbed habitats were linearly arranged in landscapes [27]. In contrast, a lack of linear barriers within landscapes increased the vulnerability of subalpine habitats to invasion by the plant Hieracium lepidulum relative to other forested habitats [25].

Connectivity within the landscape can also influence the prevalence of conflicts between humans and overabundant species. For example, as access to low-lying land and sleeping sites declined due to landscape transformation in South Africa, conflicts between humans and chacma baboon (Papio ursinus) rose as troops were relegated to sleeping and gathering in areas of high human use [28]. In that case, modification of landscape structure to provide troops access to better situated sleeping and gathering areas, but not removal of baboon troops, was deemed the only effective solution to conflicts because the high baboon densities within the landscape meant that territories vacated due to the removal of troop were rapidly resettled.

For species with symbiotic relationships, landscape connectivity can affect the behavior or distribution of hosts or vectors or, alternatively, release species from dispersal constraints. For example, connectivity was less important to animal-dispersed invasive species than to those dispersed by other vectors [29], though presumably this will vary with the ecology of the species in question, as noted earlier. For these species, the literature suggests that thoughtful consideration of connectivity requires us to move beyond cursory examinations of common landscape elements (i.e., patches, corridor habitats or land uses). In particular, the spatial distribution of host species may define the landscape structure for pathogens and pests at large spatial scales and, consequently, strongly influence movements across regions [30, 31]. For example, landscape connectivity, partly due to how landscape structure affects host distribution, can affect the spread of pathogens [32] and pests, including the maritime pine bast scale (Matuscoccus feytaudi) [33] and white pine blister rust (Cronartium ribicola) [34].

\section{Specific Land Uses within the Landscape}

The structure of a landscape reflects not only the spatial configuration of elements, but also the composition. Some studies suggest that specific land uses within the landscape are more influential than the spatial configuration of the landscape on the distribution and ecology of invasive and/or overabundant species. In these cases, the presence of or proximity to certain 
land uses within a landscape may serve as sources of individuals or propagules for invasion, accommodate critical life stages, or meet the ecological requirements of species. Propagule pressure from certain landscape elements promotes successful invasion in part by reducing the effects of demographic and environmental stochasticity $[35,36]$. Amur honeysuckle (Lonicera maackii), an invasive shrub widely used in urban landscapes, illustrates this point well. Landscape structure was the chief predictor of honeysuckle invasion, with risk greatest for woodlots nearer to towns and in landscapes with more edge [37] or adjacent urban land [38] that were rich in seeds, propagules, and dispersers. In contrast, the amount of cropland surrounding woodlots was negatively related to honeysuckle cover, probably because agricultural areas had fewer seed sources and/or animal dispersers [39]. Landscape connectivity was not important, in part because L. maackii invades from multiple foci rather than an advancing front [37].

Urbanized or built land within a landscape has been shown to promote invasion by a wide variety of species, likely due to a variety of mechanisms that include (but are not limited to) more abundant sources of invading individuals, abundant resources that can promote population growth and expansion, and reduced diversity or abundance of native species that could otherwise compete with, depredate, or parasitize invaders. Landscape structure and urbanization, in particular, determined both the spread and effect of invasive grasses on carbon cycling [40]. Species richness of non-native plants in Mediterranean habitats in northern Spain was related to patch size, shape, and especially the percent increase of built land over a 50-year period in the surrounding landscape [41]. Likewise, plant invasions were strongly associated with urban land cover in Mediterranean coastal habitats [42], rural housing in southern Wisconsin [43], and residential cover in San Juan, Puerto Rico [44]. In southern Florida, urbanization has promoted the abundance of fig-eating birds that disperse the invasive fig Ficus microcarpa [45]. Exceptions do exist, however; Gulezian and Nyberg [46] showed that abundances of nine of ten invasive plants in Chicago, IL, USA were unrelated to urbanization or other land uses. In this case, it may be that the Chicago metropolitan area has been saturated by common invaders and thus shows little variation in invasion severity. The extent to which these exceptions reflect new stable states warrants further study.

\section{Landscape Features that Act as Hubs, Corridors, or Barriers}

Certain landscape features can disproportionately impact the distribution and abundance of species. Roads are especially well known to act as corridors for the spread of invasive species, contributing to the spread of many as $69 \%$ of non-native plants in the Kashmir Valley of India [47], invasive cane toads in Australia [48], and invasive earthworms in Canada [49].
Road networks similarly played an important role in distributing emerald ash borer (Agrilus planipennis) throughout Ohio, with $84 \%$ of new sites occurring within $1 \mathrm{~km}$ of roads [50]. That said, road characteristics can mediate the extent to which they facilitate dispersal. Gelbard and Belnap [51] showed that within the same semiarid landscapes in southern Utah, the verges of paved roads contained $27 \%$ more Bromus tectorum and $50 \%$ more exotic plant species than verges of four-wheel-drive tracks. Although the difference between road types was attributed to disturbance regimes in roadside habitats that facilitated invasion rather than increased propagule pressure, both would appear to be plausible mechanisms in other roaded systems. Thus, paving appears to have the potential to dramatically increase the effectiveness of roads as corridors, even within similarly structured landscapes.

Water features are another landscape feature often associated with undesirable species. Water features, especially artificial watering ponds, can attract overabundant or invasive species including feral goats (Capra hircus; [52]) and cane toads (Bufo marinus) in Australia [53]. Specific attributes of water features may be important, such as waterbody perimeter density for Mute Swan (Cygnus olor) [54]. Invasive toads (Rhinella marina) in Australia used small dams for livestock as invasion hubs, because dams acted as refuges during dry periods and as stepping stone habitats for dispersal during wet seasons [55].

\section{Structural Legacies of Landscapes}

One striking new insight is the temporally expansive influence of landscape structure. A growing number of studies find that land use history or legacies can mediate the distribution and abundance of invasive and overabundant species [17], or conversely their effects on landscapes [56]. For example, land use history, particularly past agricultural use, predicted invasive plant distribution in the northeastern US [57] and southern Appalachian mountains [12]. Similarly, the likelihood of invasion of coastal dunes in Europe [58] and Mediterranean habitats of northern Spain [41] were also best explained by land use history. In some cases, legacy effects evident at landscape scales have local drivers, such as via fertilizer residues in former agricultural fields [59]. Overall, the existence of legacy effects suggests that predicting which sites are most likely to harbor invasive species, or most vulnerable to invasion in future, may require historical knowledge. Moreover, the presence of legacy effects after halting human activity on the landscape may complicate restoration [60]. In cases where legacy effects are irreversible, such as in systems that have moved to an alternate, novel stable state, the protection of intact habitat remnants becomes essential. 


\section{Effects of Invasive and/or Overabundant Species on Landscapes}

Ecologists have long known that organismal traits can alter a wide variety of ecosystem and landscape attributes through several pathways, including altering disturbance regimes, impacting resources through density or behavior, and directly modifying or engineering habitats. Because landscapes are emergent phenomena of processes occurring across a wide range of spatial scales, even local processes or interactions can scale up to influence landscape structure. One striking example is the landscape-scale change in forests in eastern North America elicited by the pathogenic fungus, chestnut blight (Cryphonectria parasitica; formerly Endothia parasitica) in the early 1900 s, where a once-dominant tree species was rapidly lost thereby affecting the types and distributions of forests and successional patches (following mass mortality events) within landscapes and regions. Even today non-native, invasive insects such as hemlock woolly adelgid (Adelges tsugae) and gypsy moth (Lymantria dispar) cause enormous landscape- and regional-scale changes in forests and ecosystem function by killing trees, and thereby changing forest composition and structure, biogeochemical cycling in aquatic and terrestrial systems, and species interactions [61].

Different conceptual frameworks are available to address the ways in which individual species impact ecosystems and landscapes [62]. The most common framework addresses situations in which individual species have strong effects on systems, such as keystone species, whose impacts are ecologically mediated and disproportionate to their biomass [63], ecosystem engineers that alter resource availability through non-trophic pathways [64], and foundation species that determine the physical characteristics of an area by virtue of their abundance and form [65]. A related framework views impacts through the lens of food web theory and trophic cascades [66], where trophic relationships among species define outcomes. Alternatively, some researchers view effects as a consequence of the complex assemblage of morphological, physiological, chemical, and behavioral traits of species, often referred to as functional traits [67]. The literature shows that each of these non-mutually exclusive frameworks can be useful for understanding the many ways that overabundant and/or invasive species can impact landscapes. Below, we highlight some of the most striking ways that invasive and/or overabundant species can impact landscapes.

\section{Altering Disturbance Regimes}

One profound way in which overabundant and/or invasive species can affect landscapes is by altering disturbance regimes or introducing novel disturbances [68]. For example, fire regimes can be dramatically altered by invasive species [69], and although effects vary among species, invasive grasses are widely recognized to influence fire frequency, spread, and/or extent. Mack and D'Antonio [68] reviewed 14 taxonomically distinct cases of grass invasions that increased fire frequency or intensity. In the Great Basin of North America, invasive species have contributed to changes in the fire regime that have caused landscape-scale conversions of mixed shrub-steppe habitats to grassland. Conversely, invasive trees can reduce fine fuel load by shading understory plants and lowering fire risk, as described for the shrub Mimosa pigra in the Australian floodplains [70]. Because some of these feedbacks can irreversibly alter disturbance regimes, we discuss the potential for permanent state shifts in more detail below.

Hydrology can also be altered by invading species in ways that affects landscape structure and function. Examples are common for riparian species and are documented repeatedly, such as in the case of invasive Tamarix spp., which alter flooding regimes [71]. Yet even upland systems can be strongly impacted. For instance, as the spread of hemlock woolly adelgid has killed eastern hemlocks (Tsuga canadensis), their replacement by black birch (Betula lenta) has resulted in higher evapotranspiration rates and altered annual water balances in ways that reduce stream flow and dry ephemeral streams [72]. The resulting changes in the flow of water can dramatically influence the type, arrangement, and functioning of terrestrial, aquatic, and riparian habitats throughout the affected landscapes. Interestingly, changes to water cycles driven by invasive species can also carry huge economic costs (e.g.,16 to 75 million dollars annually in the Sacramento Valley of California; [73]) and can shift patterns of water diversion and use regionally.

Geomorphological disturbances also can be affected by overabundant and/or invasive species, with some species stabilizing substrates otherwise prone to erosion, and other species increasing soil disturbance-which collectively can result in changes to landscape structure. The root structure of plants, for example, can make stream banks more or less vulnerable to erosion during high flows depending upon how easily they are uprooted. Acacia mearnsii, an Australian invader to South Africa, aggravates stream bank erosion because it is easily uprooted during high flows [74]. Erosion of stream banks can influence waterways in ways that can ultimately alter landscape structure. Invasive plants with stabilizing traits can also have major effects on the topography of landscapes, such as in the case of invasive dune grasses (e.g., Ammophila arenaria) in North America and Australia, where it is more effective at trapping and stabilizing sand and promoting new and larger dunes than those formed by native grasses [75]. 
Unlike the aforementioned cases where a species affects an abiotic process, there also are cases wherein the disturbance agents are themselves biotic in nature. For example, large-scale defoliation by invasive insects can change forest composition and successional stages across landscapes. Gandhi and Herms [61] showed that defoliation could prompt such profound changes to cause permanent state changes in ecosystems and landscapes, as shown for adelgid-infested forests. Similarly, overgrazing (grubbing) by migratory snow geese has dramatically reduced the availability of shrubby elements in arctic landscapes in recent decades [76].

Overabundant and/or invasive species can also act as "ecosystem engineers" that dramatically change the physical structure of landscapes. In some cases, these changes occur by virtue of the high densities of the offending species, but these impacts can also be disproportionate to species' biomass. For example, beaver are well known for their role as ecosystem engineers in North America, but their introduction to South America has hugely affected Patagonian steppe landscapes by causing an $85 \%$ increase in ponds from 2005 to 2014 [11], and concomitant changes in landscape processes and species distribution [77, 78]. Many ecosystem engineers are underrecognized for their roles. For example, introduced mammals on islands are well known for their disastrous effects as predators, but many also are ecosystem engineers, as demonstrated for nutria (Myocastor coypus), beaver, gray squirrel (Scurius carolinensis) [36] and deer [79]. Non-native invasive bivalves, such as zebra mussels, also act as aquatic ecosystem engineers, altering the structure and function of within-lake landscapes [80]. In general, ecosystem engineers that increase landscape complexity tend to promote species richness, whereas the opposite is true for those that reduce complexity $[64,81]$.

\section{Altering Species Interactions}

Invasive or overabundant species can indirectly influence landscapes by altering food web structure, reducing populations of species that provide critical roles in ecosystem and landscape processes, prompting surges in populations that impact systems by shifting species composition or disrupting key symbiotic interactions (e.g., pollination, seed dispersal). For example, invasive black mustard (Brassica nigra) degrades mycorrhiza and negatively affects native plants over a wide range of landscapes in North America [82]. One could also argue that invasive and overabundant species have the potential to affect entire landscapes by affecting human responses to invasion, such as decisions that affect landscapes via the widespread application of insecticides, salvage logging, crop choice, or creation of barriers to dispersal.
The effect of invasive or overabundant species on landscapes can be especially strong when they are predators, parasites, or herbivores. Non-native invasive insects, in particular, can induce positive feedbacks on ecological process and affect tropic interactions $[61,83]$. Browsing by overabundant moose (Alces alces) in Gros Morne National Park, Newfoundland, Canada caused landscape-scale changes in habitat that affected bird communities, increasing numbers of early-successional birds and reducing old forest specialists [84]. The introduction of black-tailed or Sitka deer (Odocoileus hemionus sitkensis ) to the Haida Gwaii archipelago of the Pacific Northwest of North America also dramatically altered vegetation structure and bird communities, resulting in a dramatically simplified and homogeneous structure to the archipelago landscape [85]. High levels of predation of seeds and seedlings by exotic mammals in forested landscapes of the Southern Hemisphere have arrested postfire succession and created landscapes that are now forestshrubland mosaics [86]. By disrupting sea-to-land nutrient transport by seabirds, introduced rats reduced soil fertility, which then led to a number of other cascading effects that reverberated across entire islands [87]. A similar mechanism was involved when arctic foxes (Alopex lagopus) introduced to the Aleutian Islands depredated seabirds, thereby transforming landscapes from grasslands to dwarf shrub/ forb-dominated ecosystems [88].

\section{Feedbacks and Reciprocal Effects}

As invasive and overabundant species influence communities and landscape pattern, feedbacks and reciprocal effects are likely for many species and inevitable for strong interactors. A recent review of 173 invasive plant species found that reinforcing feedbacks that caused regime shifts typically occurred in situations where seed banks, fire, or nutrient cycling had been altered by the invasive species [89]. For example, regime-shifts can be initiated when invasive grasses affect fire frequency or intensity in ways that further promote invasion. Microstegium vimineum is a non-native annual grass capable of positive invasion-fire feedbacks in deciduous forests except in wet soils [90]. Changes to the fire regimes make the landscape even more vulnerable to and likely to be dominated by invaders $[69,91]$.

White-tailed (O. virginianus) and mule deer (O. hemionus) also offer excellent examples of feedbacks, as landscape alteration, introductions and predator removal have led to massive regional increases in their densities coincident declines in plant and animal communities [92]. Deer densities, as well as the spatial patterning of nutrient subsidies by deer, are highly variable and related to landscape structure [93]. Interspersion and juxtaposition of forest and agricultural habitats are among the landscape features that predict deer 
abundance and impact [94]. Not only does deer browsing decimate native understory plants, but the effects can ripple across landscapes as browsing further enhances demographic success of other invasive plants, such as garlic mustard (Alliaria petiolate), at the expense of native plants $[95,96]$. In addition, feces of overabundant deer are important nutrient subsidies that can facilitate subsequent invasion by earthworms [97], which in turn alter the nutrient cycling, soil microbes, and understory vegetation at landscape scales [98]. Studies suggest that the ecosystem and landscape-scale changes provoked by overabundant deer force systems into alternative stable states that are difficult to reverse $[99,100]$.

\section{Conclusions}

Accumulating evidence continues to illustrate the wide range of ways that landscape structure can affect invasion processes and success, the reflexive ways in which invasions can influence landscape structure and function, and the influence of temporal stage of invasion on system state and landscape attributes. Landscape composition and configuration can create sources (or sinks) of individuals, influence movements and spread, and affect demography by mediating access to resources, species interactions, or disturbance regimes. Although species differ in their responses to landscape attributes depending upon their ecologies, the recent literature shows that invasive and/or overabundant species are often associated with landscapes that are fragmented, have corridors that facilitate spread, or include land uses that serve as sources of individuals or can provide resources. An increasing number of studies point to landscape legacies as being as important as current landscape pattern to invasion state. Our review also shows that many invasive and/or overabundant species can influence landscape structure by way of affecting keystone, foundation or engineering species, and by mediating species interactions in ways that elicit community-level change. In some instances, positive feedback cycles between landscapes and species can facilitate further invasion or population growth.

Given the importance of landscape structure on undesirable species, management should use an integrated landscape approach that identifies, in part based on landscape structure, the key places where efforts should be focused [101]. For instance, Porter et al. [102] used landscape resistance to identify specific islands where removal of mammalian mesopredators (raccoons, Procyon lotor and red fox, Vulpes vulpes) efforts would be most successful. Their data showed that islands recolonized after the removal of raccoons and red foxes had very low resistance values (i.e., energetically easier for the mammals to reach them). Likewise, invasion can be stemmed by restricting access to invasion hubs and disrupting connectivity within the landscape, as with cane toads and artificial water points in Australia [53]. Similarly, Bennett and Arcese [21] showed that the integrity of native plant communities was highest and rare species more likely to be detected in landscapes with naturally isolated fragments. These findings suggest that management actions to maintain or restore native communities may be most successful when they include measures to reduce suitability for undesirable species by careful site selection [13]. Some conservation approaches focus on modifying landscape structure to purposefully create barriers to reduce the spread of undesirable species, create refuges for native biodiversity, and reduce economic losses of invasions or other conflicts [103]. In the case of invasive insects or pathogens, establishing host-free barriers ahead of the front may slow spread and reduce damage, as was found for the invasive pathogen, Phytophthora ramorum, which causes sudden oak death [104]. Similar efforts to shield African ungulates from rinderpest by creating a cordon sanitaire around large reserves such as the Serengeti ecosystem of Tanzania helped contribute to the global eradication of that devastating disease $[105,106]$. Ultimately, understanding interactions between landscape structure and invasive and/or overabundant species has the potential to improve costefficiency of conservation investments and better prioritize conservation actions.

\section{Compliance with Ethical Standards}

Conflict of Interest On behalf of all authors, the corresponding author states that there is no conflict of interest.

\section{References}

1. Reinhardt L, Jerolmack D, Cardinale BJ, Vanacker V, Wright J. Dynamic interactions of life and its landscape: feedbacks at the interface of geomorphology and ecology. Earth Surf Process Landf. 2010;35(1):78-101.

2. Turner MG. Landscape ecology: what is the state of the science? Annu Rev Ecol Evol Syst. 2005;36:319-44.

3. Hastings A, Cuddington K, Davies KF, Dugaw CJ, Elmendorf S, Freestone A, et al. The spatial spread of invasions: new developments in theory and evidence. Ecol Lett. 2005;8(1):91-101.

4. Smith JNM, Cook TL, Rothstein SI, Robinson SK, Sealy SG. Ecology and management of cowbirds and their hosts. University of Texas Press; 2000. ISBN: 978-0-292-72689-5.

5. Merow C, LaFleur N, Silander Jr JA, Wilson AM, Rubega M. Developing dynamic mechanistic species distribution models: predicting bird-mediated spread of invasive plants across Northeastern North America. Am Nat. 2011;178(1):30-43.

6. Abraham KF, Jefferies RL, Alisauskas RT. The dynamics of landscape change and snow geese in mid-continent North America. Glob Chang Biol. 2005;11(1):841-55.

7. Blackburn TM, Pysek P, Bacher S, Carlton JT, Duncan RP, Jarosik $\mathrm{V}$, et al. A proposed unified framework for biological invasions. Trends Ecol Evol. 2011;26(7):333-9. 
8. With KA. The landscape ecology of invasive spread. Conserv Biol. 2002;16(5):1192-203.

9. Bocedi G, Zurell D, Reineking B, Travis JMJ. Mechanistic modelling of animal dispersal offers new insights into range expansion dynamics across fragmented landscapes. Ecography. 2014;37(12): $1240-53$.

10. Anderson CB, Griffith CR, Rosemond AD, Rozzi R, Dollenz O. The effects of invasive North American beavers on riparian plant communities in Cape Horn, Chile - Do exotic beavers engineer differently in sub-Antarctic ecosystems? Biol Conserv. 2006;128(4):467-74.

11. Pietrek AG, Gonzalez-Roglich M. Post-establishment changes in habitat selection by an invasive species: beavers in the Patagonian steppe. Biol Invasions. 2015;17(11):3225-35.

12. Kuhman TR, Pearson SM, Turner MG. Effects of land-use history and the contemporary landscape on non-native plant invasion at local and regional scales in the forest-dominated southern Appalachians. Landsc Ecol. 2010;25(9):1433-45.

13. Graham CA, Maron M, McAlpine CA. Influence of landscape structure on invasive predators: feral cats and red foxes in the brigalow landscapes, Queensland, Australia. Wildl Res. 2012;39(8):661-76.

14. Fraser EJ, Lambin X, Travis JMJ, Harrington LA, Palmer SCF, Bocedi G, et al. Range expansion of an invasive species through a heterogeneous landscape - the case of American mink in Scotland. Divers Distrib. 2015;21(8):888-900.

15. Bennett JR. Comparison of native and exotic distribution and richness models across scales reveals essential conservation lessons. Ecography. 2013;36:1-10.

16. Bennett JP, Cornwell W, Lilley P, Vellend M, Arcese P. Abundance, rarity and invasion debt among exotic species in a patchy ecosystem. Biol Invasions. 2013;15:707-16.

17. Vila M, Ibanez I. Plant invasions in the landscape. Landsc Ecol. 2011;26(4):461-72.

18. Clarke MF, Oldland JM. Penetration of remnant edges by noisy miners (Manorina melanocephala) and implications for habitat restoration. Wildl Restoration. 2007;34(4):253-61.

19. Montague-Drake RM, Lindenmayer DB, Cunningham RB, Stein JA. A reverse keystone species affects the landscape distribution of woodland avifauna: a case study using the Noisy Miner (Manorina melanocephala) and other Australian birds. Landsc Ecol. 2011;26(10):1383-94.

20. Bennett J, Dunwiddie P, Giblin D, Arcese P. Native versus exotic community patterns across three scales: roles of competition, environment and incomplete invasion. Perspect Plant Ecol Evol Syst. 2012;14:381-92.

21. Bennett J, Arcese P. Human influence and classic island biogeographic predictors of rare species occurrence. Conserv Biol. 2013;27:417-21.

22. Andrew ME, Ustin SL. The effects of temporally variable dispersal and landscape structure on invasive species spread. Ecol Appl. 2010;20(3):593-608.

23. Pittman SE, Muthukrishnan R, West NM, Davis AS, Jordan NR, Forester JD. Mitigating the potential for invasive spread of the exotic biofuel crop, Miscanthus $x$ giganteus. Biol Invasions. 2015;17(11):3247-61.

24. Kinezaki N, Kawasaki K, Shigesada N. The effect of the spatial configuration of habitat fragmentation on invasive spread. Theor Popul Biol. 2010;78(4):298-308.

25. Miller AU, Wiser SK, Sullivan JJ, Duncan RP. Creek habitats as sources for the spread of an invasive herb in a New Zealand mountain landscape. N Z J Ecol. 2015;39(1):71-8.

26. Maheu-Giroux M, de Blois S. Landscape ecology of Phragmites australis invasion in networks of linear wetlands. Landsc Ecol. 2007;22(2):285-301.
27. Klug PE, Reed RN, Mazzotti FJ, McEachern MA, Vinci JJ, Craven KK, et al. The influence of disturbed habitat on the spatial ecology of Argentine black and white tegu (Tupinambis merianae), a recent invader in the Everglades ecosystem (Florida, USA). Biol Invasions. 2015;17(6):1785-97.

28. Hoffman TS, O'Riain MJ. Monkey management: using spatial ecology to understand the extent and severity of human-baboon conflict in the cape peninsula, South Africa. Ecol Soc. 2012;17(3): 13.

29. Minor ES, Tessel SM, Engelhardt KAM, Lookingbill TR. The role of landscape connectivity in assembling exotic plant communities: a network analysis. Ecology. 2009;90(7):1802-9.

30. Hajek AE, Tobin PC. Introduced pathogens follow the invasion front of a spreading alien host. J Anim Ecol. 2011;80(6):1217-26.

31. Margosian ML, Garrett KA, Hutchinson JMS, With KA. Connectivity of the American agricultural landscape: assessing the national risk of crop pest and disease spread. Bioscience. 2009;59(2):141-51.

32. Papaix J, Touzeau S, Monod H, Lannou C. Can epidemic control be achieved by altering landscape connectivity in agricultural systems? Ecol Model. 2014;284:35-47.

33. Rigot T, van Halder I, Jactel H. Landscape diversity slows the spread of an invasive forest pest species. Ecography. 2014;37(7): 648-58.

34. Brar S, Tsui CKM, Dhillon B, Bergeron MJ, Joly DL, Zambino $\mathrm{PJ}$, et al. Colonization history, host distribution, anthropogenic influence and landscape features shape populations of white pine blister rust, an invasive alien tree pathogen. PLoS One. 2015;10(5):e017916.

35. Lockwood JL, Cassey P, Blackburn T. The role of propagule pressure in explaining species invasions. Trends Ecol Evol. 2005;20(5):223-8.

36. Simberloff D. Rats are not the only introduced rodents producing ecosystem impacts on islands. Biol Invasions. 2009;11(7):173542.

37. Bartuszevige AM, Gorchov DL, Raab L. The relative importance of landscape and community features in the invasion of an exotic shrub in a fragmented landscape. Ecography. 2006;29(2):213-22.

38. Borgmann KL, Rodewald AD. Forest restoration in urbanizing landscapes: interactions between land uses and an exotic shrub. Restor Ecol. 2005;13:334-40.

39. Gorchov DL, Henry MC, Frank PA. Invasion of an exotic shrub into forested stands in an agricultural matrix. Invasive Plant Sci Manag. 2014;7(2):336-44.

40. Craig ME, Pearson SM, Fraterrigo JM. Grass invasion effects on forest soil carbon depend on landscape-level land use patterns. Ecology. 2015;96:2265-79.

41. Basnou C, Iguzquiza J, Pino J. Examining the role of landscape structure and dynamics in alien plant invasion from urban Mediterranean coastal habitats. Landsc Urban Plan. 2015;136: 156-64.

42. Gonzalez-Moreno P, Pino J, Carreras D, Basnou C, FernandezRebollar I, Villa M. Quantifying the landscape influence on plant invasions in Mediterranean coastal habitats. Landsc Ecol. 2013;28:891-903.

43. Gavier-Pizarro GI, Radeloff VC, Stewart SI, Huebner CD, Keuler NS. Rural housing is related to plant invasions in forests of southern Wisconsin, USA. Landsc Ecol. 2010;25(10):1505-18.

44. Staudhammer CL, Escobedo FJ, Holt N, Young LJ, Brandeis TJ, Zipperer W. Predictors, spatial distribution, and occurrence of woody invasive plants in subtropical urban ecosystems. J Environ Manag. 2015;155:97-105.

45. Caughlin T, Wheeler JH, Jankowski J, Lichstein JW. Urbanized landscapes favored by fig-eating birds increase invasive but not native juvenile strangler fig abundance. Ecology. 2012;93(7): 1571-80. 
46. Gulezian PZ, Nyberg DW. Distribution of invasive plants in a spatially structured urban landscape. Landsc Urban Plan. 2010;95(4):161-8.

47. Dar PA, Reshi ZA, Shah MA. Roads act as corridors for the spread of alien plant species in the mountainous regions: a case study of Kashmir Valley, India. Trop Ecol. 2015;56(2):183-90.

48. Brown GP, Phillips BL, Webb JK, Shine R. Toad on the road: use of roads as dispersal corridors by cane toads (Bufo marinus) at an invasion front in tropical Australia. Biol Conserv. 2006;133(1): 88-94.

49. Cameron EK, Bayne EM, Clapperton MJ. Human-facilitated invasion of exotic earthworms into northern boreal forests. Ecoscience. 2007;14(4):482-90.

50. Prasad AM, Iverson LR, Peters MP, Bossenbroek JM, Matthews SN, Sydnor TD, et al. Modeling the invasive emerald ash borer risk of spread using a spatially explicit cellular model. Landsc Ecol. 2010;25(3):353-69.

51. Gelbard JL, Belnap J. Roads as conduits for exotic plant invasions in a semiarid landscape. Conserv Biol. 2003;17(2):420-32.

52. Letnic M, Laffan SW, Greenville AC, Russell BG, Mitchell B, Fleming PJS. Artificial watering points are focal points for activity by an invasive herbivore but not native herbivores in conservation reserves in arid Australia. Biodivers Conserv. 2015;24(1):1-16.

53. Florance D, Webb JK, Dempster T, Kearney MR, Worthing A, Letnic M. Excluding access to invasion hubs can contain the spread of an invasive vertebrate. Proc R Soc B-Biol Sci. 2011;278(1720):2900-8.

54. Weaver JE, Conway TM, Fortin M. An invasive species' relationship with environmental variables changes across multiple spatial scales. Landsc Ecol. 2012;27(9):1351-62.

55. Letnic M, Webb JK, Jessop TS, Dempster T. Restricting access to invasion hubs enables sustained control of an invasive vertebrate. J Appl Ecol. 2015;52(2):341-7.

56. Didham RK, Tylianakis JM, Hutchison MA, Ewers RM, Gemmell NJ. Are invasive species the drivers of ecological change? Trends Ecol Evol. 2005;20(9):470-4.

57. Mosher ES, Silander Jr JA, Latimer AM. The role of land-use history in major invasions by woody plant species in the northeastern North American landscape. Biol Invasions. 2009;11(10): 2317-28.

58. Malavasi M, Carboni M, Cutini M, Carranza ML, Acosta ATR. Landscape fragmentation, land-use legacy and propagule pressure promote plant invasion on coastal dunes: a patch-based approach. Landsc Ecol. 2014;29(9):1541-50.

59. Standish RJ, Cramer VA, Hobbs RJ. Land-use legacy and the persistence of invasive Avena barbata on abandoned farmland. J Appl Ecol. 2008;45(6):1576-83.

60. Cramer VA, Hobbs RJ, Standish RJ. What's new about old fields? Land abandonment and ecosystem assembly. Trends Ecol Evol. 2008;23(2):104-12.

61. Gandhi KJK, Herms DA. Direct and indirect effects of alien insect herbivores on ecological processes and interactions in forests of eastern North America. Biol Invasions. 2010;12(2):389-405.

62. Ehrenfeld JG. Ecosystem consequences of biological invasions. Annu Rev Ecol Evol Syst. 2010;41:59-80.

63. Power ME, Tilman D, Estes JA, Menge BA, Bond WJ, Mills LS, et al. Challenges in the quest for keystones. Bioscience. 1996;46(8):609-20.

64. Crooks JA. Characterizing ecosystem-level consequences of biological invasions: the role of ecosystem engineers. Oikos. 2002;97(2):153-66.

65. Ellison AM, Bank MS, Clinton BD, Colburn EA, Elliott K, Ford $\mathrm{CR}$, et al. Loss of foundation species: consequences for the structure and dynamics of forested ecosystems. Front Ecol Environ. 2005;3(9):479-86
66. Polis G, Anderson W, Holt R. Toward an integration of landscape and food web ecology: the dynamics of spatially subsidized food webs. Annu Rev Ecol Syst. 1997;28:289-316.

67. Reiss J, Bridle JR, Montoya JM, Woodward G. Emerging horizons in biodiversity and ecosystem functioning research. Trends Ecol Evol. 2009;24(9):505-14.

68. Mack MC, D'Antonio CM. Impacts of biological invasions on disturbance regimes. Trends Ecol Evol. 1998;13(5):195-8.

69. Brooks ML, D'Antonio CM, Richardson DM, Grace JB, Keeley JE, DiTomaso JM, et al. Effects of invasive alien plants on fire regimes. Bioscience. 2004;54(7):677-88.

70. Braithwaite RW, Lonsdale WM, Estbergs JA. Alien vegetation and native biota in tropical Australia: the impact of Mimosa pigra. Biol Conserv. 1989;48(3):189-210.

71. Tickner DP, Angold PG, Gurnell AM, Mountford JO. Riparian plant invasions: hydrogeomorphological control and ecological impacts. Prog Phys Geogr. 2001;25(1):22-52.

72. Daley MJ, Phillips NG, Pettijohn C, Hadley JL. Water use by eastern hemlock (Tsuga canadensis) and black birch (Betula lenta): implications of effects of the hemlock woolly adelgid. Can J For Res-Revue Canadienne De Recherche Forestiere. 2007;37(10):2031-40

73. Gerlach J. The impacts of serial land-use changes and biological invasions on soil water resources in California, USA. J Arid Environ. 2004;57(3):365-79.

74. Macdonald IAW, Richardson DM. Alien species in terrestrial ecosystems of the fynbos biome. Proceedings of the National Synthesis Symposium on the Ecology of Biological Invasions. 1986. p. 77-91.

75. Zarnetske PL, Hacker SD, Seabloom EW, Ruggiero P, Killian JR, Maddux TB, et al. Biophysical feedback mediates effects of invasive grasses on coastal dune shape. Ecology. 2012;93(6):1439-50.

76. Peterson SL, Rockwell RF, Witte CR, Koons DN. Legacy effects of habitat degradation by lesser snow Geese on nesting Savannah sparrows. Condor. 2014;116:527-37.

77. Anderson $\mathrm{CB}$, Rosemond AD. Ecosystem engineering by invasive exotic beavers reduces in-stream diversity and enhances ecosystem function in Cape Horn, Chile. Oecologia. 2007;154(1): 141-53.

78. Anderson CB, Martines Pastur G, Lencinas MV, Wallem PK, Moorman MC, Rosemond AD. Do introduced North American beavers Castor canadensis engineer differently in southern South America? An overview with implications for restoration. Mammal Rev. 2009;39:33-52.

79. Arcese P, Schuster R, Campbell L, Barber A, Martin TG. Deer density and plant palatability predict shrub cover, richness, diversity and aboriginal food value in a North American archipelago. Divers Distrib. 2014;20:1338-78.

80. Sousa R, Gutierrez JL, Aldridge DC. Non-indigenous invasive bivalves as ecosystem engineers. Biol Invasions. 2009;11(10): 2367-85.

81. Estes JA, Terborgh J, Brashares JS, Power ME, Berger J, Bond WJ, et al. Trophic downgrading of planet earth. Science. 2011;333:301-6.

82. Pakpour S, Klironomos J. The invasive plant, Brassica nigra, degrades local mycorrhizas across a wide geographical landscape. R Soc Open Sci. 2015;2(9):150300.

83. Kenis M, Auger-Rozenberg M, Roques A, Timms L, Pere C, Cock MJW, et al. Ecological effects of invasive alien insects. Biol Invasions. 2009;11(1):21-45.

84. Rae LF, Whitaker DM, Warkentin IG. Multiscale impacts of forest degradation through browsing by hyperabundant moose (Alces alces) on songbird assemblages. Divers Distrib. 2014;20(4):38295.

85. Martin J-L, Stockton SA, Allombert S, Gaston AJ. Top-down and bottom-up consequences of unchecked ungulate browsing on 
plant and animal diversity in temperate forests: lessons from a deer introduction. Biol Invasions. 2009;12:353-71.

86. Perry GLW, Wilmshurst JM, Ogden J, Enright NJ. Exotic mammals and invasive plants alter fire-related thresholds in southern temperate forested landscapes. Ecosystems. 2015;18(7):1290 305.

87. Fukami T, Wardle DA, Bellingham PJ, Mulder CPH, Towns DR, Yeates GW, et al. Above- and below-ground impacts of introduced predators in seabird-dominated island ecosystems. Ecol Lett. 2006;9(12):1299-307.

88. Croll DA, Maron JL, Estes JA, Danner EM, Byrd GV. Introduced predators transform subarctic islands from grassland to tundra. Science. 2005;307(5717):1959-61.

89. Gaertner M, Biggs R, Te Beest M, Hui C, Molofsky J, Richardson DM. Invasive plants as drivers of regime shifts: identifying highpriority invaders that alter feedback relationships. Divers Distrib. 2014;20(7):733-44.

90. Wagner SA, Fraterrigo JM. Positive feedbacks between fire and non-native grass invasion in temperate deciduous forests. For Ecol Manag. 2015;354:170-6.

91. Grigulis K, Lavorel S, Davies ID, Dossantos A, Lloret F, Vila M. Landscape-scale positive feedbacks between fire and expansion of the large tussock grass, Ampelodesmos mauritanica in Catalan shrublands. Glob Chang Biol. 2005;11:1042-53.

92. Chollet S, Martin JL. Declining woodland birds in North America: should we blame Bambi? Divers Distrib. 2013;19:481-3.

93. Seagle SW. Can ungulates foraging in a multiple-use landscape alter forest nitrogen budgets? Oikos. 2003;103(1):230-4.

94. Hurley PM, Webster CR, Flaspohler DJ, Parker GR. Untangling the landscape of deer overabundance: Reserve size versus landscape context in the agricultural Midwest. Biol Conserv. 2012;146(1):62-71.

95. Gonzales EK, Arcese P. Herbivory, more than competition, limits early and established life stages of native plants in an invaded oak meadow. Ecology. 2008;89:3282-9.

96. Kalisz S, Spigler RB, Horvitz CC. In a long-term experimental demography study, excluding ungulates reversed invader's explosive population growth rate and restored natives. Proceedings of the National Academy of Sciences, U.S.A., 2014;111: 4501-6.

97. Karberg NJ, Lilleskov EA. White-tailed deer (Odocoileus virginianus) fecal pellet decomposition is accelerated by the invasive earthworm Lumbricus terrestris. Biol Invasions. 2009;11(3): 761-7.

98. Addison JA. Distribution and impacts of invasive earthworms in Canadian forest ecosystems. Biol Invasions. 2009;11:59-79.

99. Cote SD, Rooney TP, Tremblay JP, Dussault C, Waller DM. Ecological impacts of deer overabundance. Annu Rev Ecol Evol Syst. 2004;35:113-47.

100. Tanentzap AJ, Burrows LE, Lee WG, Nugent G, Maxwell JM, Coomes DA. Landscape-level vegetation recovery from herbivory: progress after four decades of invasive red deer control. J Appl Ecol. 2009;46(5):1064-72.

101. Glen AS, Pech RP, Byrom AE. Connectivity and invasive species management: towards an integrated landscape approach. Biol Invasions. 2013;15(10):2127-38.

102. Porter JH, Dueser RD, Moncrief ND. Cost-distance analysis of mesopredators as a tool for avian habitat restoration on a naturally fragmented landscape. J Wildl Manag. 2015;79(2):220-34.

103. Hermoso V, Januchowski-Hartley SR, Linke S. Systematic planning of disconnection to enhance conservation success in a modified world. Sci Total Environ. 2015;536:1038-44.

104. Filipe JAN, Cobb RC, Meentemeyer RK, Lee CA, Valachovic YS, Cook AR, et al. Landscape epidemiology and control of pathogens with cryptic and long-distance dispersal: Sudden Oak death in northern Californian forests. Plos Computational Biol. 2012;8(1):e1002328.

105. Mariner JC, House JA, Mebus CA, Sollod AE, Chibeu D, Jones $\mathrm{BA}$, et al. Rinderpest eradication: appropriate technology and social innovations. Science. 2012;337:1309-12.

106. Sinclair ARE, Arcese P. Serengeti in the context of global conservation. In: Sinclair ARE, Arcese P, editors. Serengeti II: research, management and conservation of an ecosystem. University of Chicago Press; 1995. p. 31-46. 